\title{
Mineralocorticoid Receptor Antagonists in Diabetic Kidney Disease
}

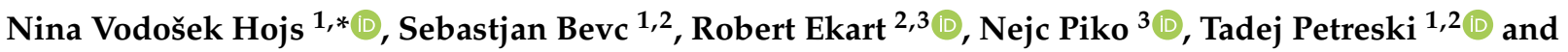 \\ Radovan Hojs ${ }^{1,2}$ \\ 1 Department of Nephrology, Clinic for Internal Medicine, University Medical Centre Maribor, \\ Ljubljanska ulica 5, 2000 Maribor, Slovenia; sebastjan.bevc@gmail.com (S.B.); tadej.petreski@gmail.com (T.P.); \\ radovan.hojs@guest.arnes.si (R.H.) \\ 2 Faculty of Medicine, University of Maribor, Taborska ulica 8, 2000 Maribor, Slovenia; \\ robert.ekart2@guest.arnes.si \\ 3 Department of Dialysis, Clinic for Internal Medicine, University Medical Centre Maribor, Ljubljanska ulica 5, \\ 2000 Maribor, Slovenia; nejc.piko@gmail.com \\ * Correspondence: nina.hojs1@gmail.com; Tel.: +386-41-366-133; Fax: +386-2-321-28-45
}

check for updates

Citation: Vodošek Hojs, N.; Bevc, S.; Ekart, R.; Piko, N.; Petreski, T.; Hojs, R. Mineralocorticoid Receptor Antagonists in Diabetic Kidney Disease. Pharmaceuticals 2021, 14, 561. https://doi.org/10.3390/ph14060561

Academic Editors: Swayam

Prakash Srivastava and Surya Pandey

Received: 25 May 2021

Accepted: 8 June 2021

Published: 11 June 2021

Publisher's Note: MDPI stays neutral with regard to jurisdictional claims in published maps and institutional affiliations.

Copyright: (c) 2021 by the authors. Licensee MDPI, Basel, Switzerland. This article is an open access article distributed under the terms and conditions of the Creative Commons Attribution (CC BY) license (https:// creativecommons.org/licenses/by/ $4.0 /)$.

\begin{abstract}
Diabetes mellitus is a global health issue and main cause of chronic kidney disease. Both diseases are also linked through high cardiovascular morbidity and mortality. Diabetic kidney disease (DKD) is present in up to $40 \%$ of diabetic patients; therefore, prevention and treatment of DKD are of utmost importance. Much research has been dedicated to the optimization of DKD treatment. In the last few years, mineralocorticoid receptor antagonists (MRA) have experienced a renaissance in this field with the development of non-steroidal MRA. Steroidal MRA have known cardiorenal benefits, but their use is limited by side effects, especially hyperkalemia. Non-steroidal MRA still block the damaging effects of mineralocorticoid receptor overactivation (extracellular fluid volume expansion, inflammation, fibrosis), but with fewer side effects (hormonal, hyperkalemia) than steroidal MRA. This review article summarizes the current knowledge and newer research conducted on MRA in DKD.
\end{abstract}

Keywords: diabetic kidney disease; chronic kidney disease; mineralocorticoid receptor antagonists; spironolactone; eplerenone; apararenone; esaxerenone; finerenone

\section{Introduction}

Diabetes mellitus (DM) is a worldwide health issue and it is estimated that it affected 463 million adults in 2019 [1]. Up to forty percent of these patients have diabetic kidney disease (DKD), making it the most common cause of chronic kidney disease [2]. DM patients suffer from excess morbidity, cardiovascular and all-cause mortality [3,4]. Cardiovascular and all-cause mortality is further increased by the presence of chronic kidney disease [5-7]. Patients with DM have a 10-year life span loss while those with DKD have a 16-year life span loss [8]. DM and its complications present not only a personal, but also a major economic burden $[9,10]$.

DKD is a microvascular complication. Although the gold standard for DKD confirmation is kidney biopsy, it is mostly not performed because of its invasive nature. Clinical identification of DKD is based upon at least 3 months of decreased estimated glomerular filtration rate $\left(\mathrm{eGFR}<60 \mathrm{~mL} / \mathrm{min} / 1.73 \mathrm{~m}^{2}\right.$ ) and/or presence of albuminuria (urinary albumin-creatinine ratio (UACR) $\geq 30 \mathrm{mg} / \mathrm{g}$ ) in a patient with DM. Albuminuria is also an important risk marker; it is associated with kidney disease progression, risk of end-stage kidney disease, cardiovascular morbidity and mortality [11,12]. Risk factors for DKD are various (sex, age, ethnicity, hyperglycemia, arterial hypertension, obesity, smoking, etc.), but the leading ones are hyperglycemia and arterial hypertension [13]. Therefore, treatment of DKD encompasses appropriate lifestyle changes (i.e., weight reduction, physical activity, 
appropriate diet, smoking cessation), glycemic and blood pressure control [14]. The cornerstone of therapy in patients with albuminuria are angiotensin-converting enzyme (ACE) inhibitors or angiotensin receptor blockers (ARB), which slow down the rate of kidney function decline [15]. However, they do not reduce the number of cardiovascular events [16]. In the last few years, sodium-glucose co-transporter-2 (SGLT2) inhibitors made it to the forefront by lowering blood sugar, blood pressure, reducing kidney function decline and improving cardiovascular outcomes [17-20]. Since 2019, SGLT2 inhibitors have been part of the recommended treatment of DKD by the American Diabetes Association. Glucagonlike peptide-1 (GLP1) agonists also improve glycemic control, decrease cardiovascular outcomes and moderately decrease kidney outcomes [21]. Other hypoglycemic agents with potential benefit in DKD are dipeptidyl peptidase 4 (DPP4) inhibitors, but further research needs to be conducted $[22,23]$. Despite all these treatment options, current management of DKD still leaves a substantial residual risk for kidney disease progression, morbidity and mortality. Therefore, novel treatments are being developed that target inflammation, fibrosis, oxidative stress, renal hemodynamics, glomerular hyperfiltration, the endothelin system, janus kinase (JAK)-signal transducer and activator of transcription (STAT) pathway, etc. [14,24]. Recently, a selective endothelin A receptor antagonist atrasentan was shown to lower the risk of renal events in carefully selected patients with DKD [25]. Baricitinib, a JAK1 and 2 inhibitor, was also shown to reduce albuminuria in DKD patients [26]. New potential treatment targets are continuously being recognized, such as N-acetyl-serylaspartyl-lysyl-proline (AcSDKP), sirtuin 3 (SIRT3), glycolysis inhibitors, pyruvate kinase M2 type (PKM2) activators, etc. $[27,28]$. New insights into the pathophysiology of DKD are also being obtained. For example, it was found that loss of endothelial glucocorticoid receptors accelerates diabetic nephropathy in mice [29]. However, further research and large-scale randomized controlled trials are necessary before new treatments are utilized in everyday clinical practice.

Among novel treatments, mineralocorticoid receptor antagonists (MRA) are in the limelight. The focus of this article is to conduct an in-depth review of mineralocorticoid receptors (MR) and their antagonists, focusing on the ones used in clinical practice or latest clinical research. For each of them, we make a short pharmacological introduction, followed by some key clinical trials in cardiovascular medicine because of the importance of cardiovascular diseases in DKD. This is followed by research conducted on DKD.

\section{Mineralocorticoids and the Mineralocorticoid Receptors (MR)}

The last few decades have seen a major shift in the understanding of the role of mineralocorticoids and MR at the physiological and pathophysiological level.

Mineralocorticoids are steroid hormones; the main physiological mineralocorticoid is aldosterone. It is synthesized in the outer layer of the adrenal gland in response to hyponatremia and hyperkalemia, through the activation of the renin-angiotensin system (RAS) [30]. However, it can also be produced locally in peripheral tissues [31]. Aldosterone's classical, renal/epithelial and main role is in the control of blood pressure and extracellular volume homeostasis through sodium reabsorption and potassium excretion. Later it became clear that it also has extrarenal/non-epithelial effects by stimulating inflammation, fibrosis and necrosis. An important contribution to this knowledge came from Hans Seyle and his colleagues. They showed the pro-inflammatory and pro-fibrotic effects of mineralocorticoids and attenuation of these effects by an aldosterone antagonist spironolactone in animal models [32-34]. Sadly, these results were not adequately noticed and were forgotten for many decades. Awareness was raised again in the 1990s through the experiments performed by Brilla and colleagues. They showed that mineralocorticoid excess in rats contributed to cardiac fibrosis independent of high blood pressure $[35,36]$. Additionally, they found that the aldosterone antagonist spironolactone prevented perivascular and interstitial cardiac fibrosis in rats regardless of arterial hypertension and left ventricle hypertrophy [37]. 
MR are intracellular receptors and act as nuclear transcription factors ("genomic" effect) or have rapid non-genomic effects through secondary cell signaling mechanisms [38-40]. They are expressed in many tissues, including the kidney, heart, vasculature, nervous and immune system. Although it was originally thought that only mineralocorticoids bind to them, it was later found that aldosterone, cortisol, and progesterone bind to them with the same affinity [41]. Progesterone acts as an MR antagonist. Levels of plasma cortisol are much higher than aldosterone levels. In "aldosterone target cells" (renal tubular epithelial cells, sweat glands, salivary glands, colon, vascular endothelial cells, smooth muscle cells, some brain cells), cortisol is mostly converted by $11 \beta$-hydroxysteroid dehydrogenase type 2 (11 $\beta$-HSD2) into an inactive metabolite $[42,43]$. Therefore, aldosterone can activate the MR even at lower concentrations. In $11 \beta$-HSD2-deficient cells, cortisol normally acts as an antagonist-it binds to the MR and does not activate it [41]. However, in tissue damage the cortisol-MR complex may become activated and, in this case, cortisol acts as an MR agonist. Cortisol may also act as an MR agonist in certain other states, as is the case in aldosterone deficiency [44]. Importantly, the aldosterone-MR complex is more stable, being 200 times more active for transactivation than the cortisol-MR complex [45]. The process of MR activation is also regulated by different cofactors in a ligand and cell-type specific way, leading to different physiological responses [46,47]. Additionally, MR expression can be modified in disease states [45]. MR affect fluid, electrolyte and hemodynamic homeostasis, as well as tissue remodeling [46]. Increased MR activity can be driven by increased levels of aldosterone, a shift in cortisol activity from MR antagonist to MR agonist or raised local expression of the MR [48]. MR overactivation can lead to inflammation, increased oxidative stress, necrosis, fibrosis and finally, organ damage. It has been linked to arterial hypertension, coronary artery disease, heart failure, metabolic syndrome, DM and chronic kidney disease [15,49-52].

\section{Mineralocorticoid Receptor Antagonists (MRA)}

Historically, MRA started as aldosterone antagonists. At that time, it was not yet known that the aldosterone receptor is promiscuous. Interestingly, the first MRA spironolactone was developed in 1957, shortly after aldosterone purification, and 30 years before the complementary DNA (cDNA) of the MRA was cloned [53]. Its structure was based on the naturally occurring antagonist progesterone. Spironolactone is a steroidal MRA and the first "anti-hormone" used in clinical practice [54]. Because of its low selectivity, newer and more selective MRA were sought, and another steroidal MRA, eplerenone, was developed. Steroidal MRA were discovered and characterized by experiments on animals and humans. In search of new, even more selective and potent MRA, pharmaceutical companies used computer screening of different compounds [53]. This was possible only after the cDNA of the whole steroid hormone receptor family was cloned. The search led to the discovery of non-steroidal MRA; currently, the most advanced compounds are apararenone, esaxerenone and finerenone. They differ from steroidal MRA in their pharmacokinetics, tissue distribution, mode of action, effects on cofactor recruitment and effects on inflammation and fibrosis [30].

MRA were first used in clinical trials in cardiovascular diseases, especially in patients with heart failure. Later, their role in chronic kidney disease evolved. The first meta-analysis looking at the role of spironolactone and eplerenone in chronic kidney disease patients already treated with RAS inhibitors showed that MRA reduce proteinuria and increase the risk of hyperkalemia [55]. In the latest meta-analysis, the use of MRA (spironolactone, eplerenone, finerenone) alone or on top of RAS inhibitors had a significant antiproteinuric effect in chronic kidney disease patients [56]. Compared to placebo, MRA decreased UACR by $24.6 \%$, urine protein-creatinine ratio by $53.9 \%$ and $24 \mathrm{~h}$ albuminuria by $32.5 \%$. All this is likely to be clinically relevant since $>30 \%$ albuminuria reduction in comparison to placebo has been shown to reduce the risk of end-stage kidney disease development [57]. In the same meta-analysis, they also showed that MRA were associated with a slight decrease in 
eGFR $\left(2.4 \mathrm{~mL} / \mathrm{min} / 1.73 \mathrm{~m}^{2}\right)$, a small increase in mean potassium level $(0.2 \mathrm{mEq} / \mathrm{L})$ and a 2.6-fold increase in hyperkalemia risk compared with placebo/active control [56].

DKD is a form of chronic kidney disease that is mostly driven by renal and vascular inflammation, matrix formation and fibrosis [15]. Inflammation affecting the podocytes leads to albuminuria, which leads to kidney disease progression and is associated with high cardiovascular risk [58]. The inflammatory and proliferative response in DKD is stimulated by relative aldosterone excess [15]. This persists even after the use of ACE inhibitors or ARB, due to the so-called aldosterone escape phenomenon [15]. Namely, aldosterone secretion is not only stimulated by angiotensin II, but also by other stimuli like hyperkalemia and atrial natriuretic peptide [15]. MRA present a hot research topic in DKD.

\section{Steroidal MRA}

\subsection{Spironolactone}

Spironolactone is one of the spirolactones, i.e., steroids that contain a $\gamma$-lactone or a $\gamma$-hydroxy acid function at C-17 [53]. Two other important spirolactones, SC-5233 (3-(3-oxo$17 \beta$-hydroxy-4-androsten-17 $\alpha$-yl)propionic acid $\gamma$-lactone) and SC-8109 (19-nor analog of SC-5233) were the first studied steroidal MRA. Liddle was the first to use a steroidal MRA in humans and showed that SC-5233 induced natriuresis in seven edematous patients due to congestive heart failure or nephrosis [59]. The problem with these spirolactones was that they had to be administered parenterally to achieve a sufficient effect. Therefore, these compounds were chemically modified and in 1957 the first oral MRA spironolactone (SC-9420; $7 \alpha$-acetylthio-17 $\alpha$-hydroxy-3-oxopregn-4-ene-21-carboxylic acid $\gamma$-lactone) was developed [53]. In 1960 it was approved by the FDA for use as a diuretic in the management of edema, arterial hypertension and primary hyperaldosteronism.

Spironolactone binds to the MR at the same site as aldosterone. It has a high affinity for the MR, but dissociates more quickly, destabilizes the receptor and hinders coactivator recruitment [60]. Depending on promoters and cell type, it also has partial agonist effects [60]. It is highly bound to plasma proteins (around 90\%). It has a short half-life of $1-2 \mathrm{~h}$, and is metabolized into more active metabolites, the most important ones being $7 \alpha$-thiomethylspironolactone and canrenone [42,61]. In some countries, canrenone is also marketed as an independent drug formulation. The main metabolites have half-lives of 18-24 h; therefore, spironolactone can be administered once daily [42]. Based on quantitative whole-body autoradiography in rodents, it reaches a six times higher concentration in the kidneys than in the heart [60]. Spironolactone is not a very selective MR antagonist, it also acts as an antagonist of the androgen receptor leading to gynecomastia and impotence, and as an agonist of the progesterone receptor causing menstrual irregularities [42]. Another important side effect, especially in chronic kidney disease patients receiving RAS inhibitors, is hyperkalemia. Despite its side effects, it is still in widespread clinical use. It is prescribed in doses from $12.5 \mathrm{mg}$ and up to $400 \mathrm{mg}$ daily, depending on the indication [62].

The first important clinical trials with spironolactone were performed in patients with cardiovascular diseases. In 1999, a key clinical trial of spironolactone use in heart failure patients with reduced ejection fraction $(\leq 35 \%)$ was published (Randomized ALdactone Evaluation Study (RALES)) [63]. They treated 1663 patients with spironolactone or placebo and the trial was discontinued early because of efficacy. They found a 30\% reduction of mortality risk, lower frequency of hospitalizations for worsening heart failure and improvement of heart failure symptoms in the spironolactone group. However, when Pitt et al. used spironolactone and placebo in heart failure patients with preserved ejection fraction $(\geq 45 \%)$ (Treatment of Preserved Cardiac Function Heart Failure with an Aldosterone Antagonist (TOPCAT) trial), spironolactone did not reduce the incidence of death from cardiovascular causes, nor did it abort cardiac arrest or reduce hospitalization for the management of heart failure [64]. In 2016, Beygui et al. (Aldosterone Lethal effects Blocked in Acute myocardial infarction Treated with or without Reperfusion to improve Outcome and Survival at Six months follow-up (ALBATROSS) trial) also could not show the advantage of MRA 
use (one intravenous bolus of potassium canrenoate followed by oral spironolactone for 6 months) added to standard therapy in patients with acute myocardial infarction [65].

\section{Spironolactone and DKD}

Since spironolactone has the longest history of all the MRA, most of the studies with MRA in DKD were performed with it. Different tissue and animal studies proved its renoprotective effects [66-72]. In 2001, Miric et al. published a study that showed that short-term treatment with spironolactone in streptozotocin-diabetic rats reversed renal and cardiac fibrosis [66]. In the same animal model, Fujisawa et al. showed that spironolactone attenuated renal fibrosis and suppressed macrophage infiltration, plasminogen activator inhibitor-1 (PAI- 1 ) and transforming growth factor- $\beta 1$ (TGF- $\beta 1$ ) expression in glomeruli and tubulointerstitium [67]. Han et al. showed that spironolactone reduces albuminuria, inflammation and glomerulosclerosis in diabetic rats, and that it inhibits nuclear factor$\kappa B(N F-\kappa B)$ activation and monocyte chemoattractant protein-1 (MCP-1) production in cultured intrinsic renal cells [68]. Yuan et al. and Pessoa et al. additionally showed that spironolactone reduces oxidative stress in diabetic rats $[69,71]$.

Until today, many studies have been performed on the use of spironolactone in patients with DKD; here, we will highlight just some of them. The first report of proteinuria reduction from spironolactone as an add-on therapy to a RAS inhibitor in chronic kidney disease patients ( 5 out of 8 had DKD) dates back to 2001 [73]. This was followed by a study by Sato et al. that showed aldosterone escape in $40 \%$ of their 45 type 2 DM patients with early nephropathy treated with a RAS inhibitor [74]. These patients had significantly higher albuminuria than patients without aldosterone escape. Adding spironolactone $25 \mathrm{mg}$ to their treatment significantly reduced albuminuria without changes in serum potassium. The first small, double-blinded, controlled, 2-period crossover study was performed by Rosing et al. [75]. Twenty-one type $2 \mathrm{DM}$ patients with nephropathy were treated with spironolactone $25 \mathrm{mg}$ once daily or placebo for 8 weeks, in addition to a maximally recommended dose of a RAS inhibitor. Spironolactone significantly reduced albuminuria and blood pressure, but the change in albuminuria was not correlated with the change in blood pressure. A few months later a similar study in type $1 \mathrm{DM}$ patients was published; they came to the same conclusion as the previous study [76]. The antiproteinuric effect of spironolactone was later also confirmed to be long-lasting (one-year follow-up) in a study of type 2 DM patients with macroalbuminuria on treatment with RAS inhibitors [77]. Takebayashi et al. found that spironolactone inhibits the production of urinary MCP-1 and reduces oxidative stress (urinary 8-iso-prostaglandin F2 $\alpha$ ) independently of blood pressure in type 2 DM patients with nephropathy [78]. Nielsen et al. found that spironolactone treatment in DKD did not change markers of inflammation and endothelial dysfunction [79]. Later, Mehdi et al. performed a study on 81 patients with DM and arterial hypertension, all receiving lisinopril ( $80 \mathrm{mg}$ once daily) [80]. They were randomly assigned to receive a placebo, losartan ( $100 \mathrm{mg}$ daily), or spironolactone ( $25 \mathrm{mg}$ daily) for 48 weeks. The addition of spironolactone, but not losartan, reduced albuminuria significantly in comparison to placebo. There was no difference in blood pressure changes between groups. In another study, Esteghmati et al. also showed that spironolactone in combination with an ARB is more effective than the combination of an $\mathrm{ARB}$ and $\mathrm{ACE}$ inhibitor in reducing albuminuria in type $2 \mathrm{DM}$ patients treated for 18 months [81]. Maklough et al. showed that spironolactone alone is as effective as the combination of spironolactone and losartan on albuminuria reduction in type $2 \mathrm{DM}$ patients [82].

Two meta-analyses were published on the treatment of spironolactone in combination with a RAS inhibitor in DKD $[83,84]$. The addition of spironolactone significantly reduced albuminuria in comparison to monotherapy with a RAS inhibitor [84]. Spironolactone significantly increased the serum/plasma creatinine without a significant change in eGFR [84]. Spironolactone also significantly increased serum/plasma potassium levels and the risk for hyperkalemia $[83,84]$. 
The latest research goes in the direction of personalized medicine and optimization of therapy through the identification of urinary metabolites, reflecting inflammation and fibrosis, and consequently predicting albuminuria response of patients with DKD to spironolactone [85]. Mulder et al. identified such a set of 18 urinary metabolites [85]. In the PRIORITY (Proteomic prediction and Renin angiotensin aldosterone system Inhibition prevention of early diabetic nephRopathy In TYpe 2 diabetic patients with normoalbuminuria) study a urinary proteomic risk classifier (CKD273) score was tested in type 2 DM patients with preserved renal function and without albuminuria [86]. They found that CKD273 was associated with an increased risk of progression to albuminuria over a median of 2.5 years, independent of clinical characteristics. However, spironolactone did not prevent progression to albuminuria in these high-risk patients.

\subsection{Eplerenone}

Eplerenone (CGP-30083; 9-11 $\alpha$-epoxymexrenone) is a steroidal MRA, a derivative of spironolactone that has a lower affinity for the MR than spironolactone but a much higher selectivity $[45,87]$. After binding to the MR it stabilizes it in a transcriptionally inert conformation and does not actively recruit corepressors [88]. It has a higher bioavailability than spironolactone since only fifty percent of it is bound to plasma proteins [60]. Its half-life is $4-6 \mathrm{~h}$ and it has no active metabolites [30]. In spite of its short half-life, its anti-mineralocorticoid activity can last up to $12 \mathrm{~h}$, probably because of downstream MR signaling inhibition leading to natriuresis over time [60]. Based on quantitative wholebody autoradiography in rodents it achieves a three times higher concentration in the kidneys than in the heart [60]. Because of its selectivity it lacks the sexual side effects of spironolactone. Hyperkalemia is also an issue in chronic kidney disease patients or with concomitant use of RAS inhibitors [15,89]. First clinical studies with eplerenone date back to 1989, but it was approved by the FDA in 2002 for arterial hypertension and 2003 for symptomatic heart failure with reduced ejection fraction after an acute myocardial infarction $[61,90]$. It is available in two doses $-25 \mathrm{mg}$ and $50 \mathrm{mg}$. The starting dose for heart failure is $25 \mathrm{mg}$ once daily that can be up titrated to $50 \mathrm{mg}$ once daily, while the starting dose for arterial hypertension is $50 \mathrm{mg}$ once daily and can be increased to $50 \mathrm{mg}$ twice daily [91].

An important study of the effect of eplerenone in arterial hypertension patients was conducted by Weinberger et al. [92]. They showed that eplerenone significantly reduced blood pressure in comparison to placebo without serious side effects. The antihypertensive effect was dose-dependent. However, eplerenone was less effective in blood pressure lowering than spironolactone. Eplerenone $100 \mathrm{mg}$ once daily or $50 \mathrm{mg}$ twice daily had an efficacy of $50-75 \%$ compared to spironolactone $50 \mathrm{mg}$ twice daily. A seminal study of eplerenone use was conducted by Pitt et al. [93]. It was a placebo-controlled study in 6632 patients with acute myocardial infarction complicated by left ventricular dysfunction and heart failure (Eplerenone Post-Acute Myocardial Infarction Heart Failure Efficacy and Survival Study (EPHESUS)). During a mean follow-up of 16 months, eplerenone reduced morbidity and mortality in these patients. Another important study in heart failure patients is the Eplerenone in Mild Patients Hospitalization And SurvIval Study in Heart Failure (EMPHASIS-HF) [94]. In this study, 2737 patients with New York Heart Association class II heart failure and an ejection fraction of no more than $35 \%$ received eplerenone or placebo, in addition to standard recommended therapy. The study was prematurely stopped since eplerenone significantly reduced the risk of death and hospitalizations for heart failure in comparison to placebo. Included DM patients only had mild hyperkalemia; no significant increase in serum potassium or discontinuation of the drug occurred [95]. Additional analysis of 1846 initially non-diabetic patients from the EMPHASIS-HF study showed that eplerenone had no effect on new-onset DM [96]. Eplerenone was also studied in patients with acute myocardial infarction with ST-elevation without known heart failure, receiving standard medical care [97]. Its use was safe and well tolerated, it reduced the level of brain natriuretic peptides, but no other clear benefit was found. 


\section{Eplerenone and DKD}

Eplerenone was used in animal experiments of DKD. Guo et al. studied uninephrectomized diabetic rats (DM type 1 model) and mice (DM type 2 model) [98]. Diabetic rodents showed increased expression of the MR. In both models, eplerenone significantly reduced albuminuria and kidney lesions (glomerular hypertrophy, mesangial proliferation, tubulointerstitial injury, etc.), and increased renal cortical levels of MR messenger RNA (mRNA), TGF- $\beta$ mRNA and osteopontin mRNA. These changes were not a result of blood pressure or glycemia changes. Lian et al. studied the effect of eplerenone in a type 1 diabetic rat model [99]. Eplerenone decreased albuminuria, glomerular volume, TGF- $\beta 1$ expression and glomerular collagen IV without changing glomerular macrophage infiltration. Kang et al. studied the effect of eplerenone and enalapril treatment in type 2 diabetic rats [100]. Both drugs improved albuminuria, glomerular filtration rate and glomerulosclerosis, with the most distinctive changes seen in the combination group. Zhou et al. performed a study in uninephrectomized type 2 diabetic mice [101]. Untreated mice developed progressive albuminuria, glomerulosclerosis, decreased number of podocytes, increased renal expression of fibrotic markers, markers of inflammation and oxidative stress. After treatment with eplerenone, enalapril or both, all these changes were reduced or the progression of changes was arrested, mostly with the combination of both drugs.

Only two published clinical studies exist on the use of eplerenone in type $2 \mathrm{DM}$ patients with albuminuria. The first one was a 24-week, double-blind study of 215 type $2 \mathrm{DM}$ patients with mild-to-moderate arterial hypertension and albuminuria (UACR $\geq 50 \mathrm{mg} / \mathrm{g}$ ) [102] Patients randomly received eplerenone $200 \mathrm{mg}$ or enalapril $40 \mathrm{mg}$ or the combination of eplerenone $200 \mathrm{mg}$ and enalapril $10 \mathrm{mg}$ once daily. Eplerenone alone or in combination caused a significant reduction of UACR, independent of blood pressure reduction. Hyperkalemia was an issue; therefore, another study was conducted with lower eplerenone doses. In this study, 268 type $2 \mathrm{DM}$ patients with albuminuria (UACR $\geq 50 \mathrm{mg} / \mathrm{g}$ ) after an open-label run-in with enalapril $20 \mathrm{mg}$ daily were assigned to a 12-week treatment with eplerenone $50 \mathrm{mg}$ or $100 \mathrm{mg}$ or placebo once daily [103]. UACR was significantly reduced from baseline in both eplerenone groups (50 mg: $41.0 \%, 100 \mathrm{mg}: 48.4 \%$ ) but not in the placebo group (7.4\%). No significant differences in hyperkalemia between groups were detected. Even so, according to the label, eplerenone prescription is contraindicated in patients with renal dysfunction or for the treatment of arterial hypertension in type $2 \mathrm{DM}$ patients with albuminuria [91].

\section{Non-Steroidal MRA}

\subsection{Apararenone}

Apararenone (MT-3995; N-[4-(4-fluorophenyl)-2,2-dimethyl-3-oxo-3,4-dihydro-2H1,4-benzoxazin-7-yl]methanesulfonamide) is a benzoxazinone derivative [104]. It is a long-acting, highly selective MRA [105,106]. Its major metabolite is 1118174 , which has $1 / 50$ of apararenone's affinity to bind to the MR. Currently, very little data are available about apararenone. It was used in a phase 2 clinical trial in patients with nonalcoholic steatohepatitis, but data are not yet published [87].

The only published study of apararenone use was performed in DKD patients [107]. It included 293 Japanese patients with type $2 \mathrm{DM}$ and albuminuria. In the first part of the study, patients received placebo or different dosages of apararenone for 24 weeks. After this, some of the patients were included in an uncontrolled extension study of 28 weeks. Apararenone significantly reduced UACR in comparison to placebo. After 24 weeks, the percent reduction from baseline in UACR was around $40-50 \%$ in all patients receiving apararenone. The UACR lowering effect was confirmed with or without concomitant use of RAS inhibitors. After 52 weeks, the percent reduction from baseline in UACR was approximately $60 \%$ in apararenone $5 \mathrm{mg}$ and $10 \mathrm{mg}$ groups. eGFR decreased, while serum potassium increased, but changes were not clinically significant. In this study, apararenone appeared to be safe and tolerable; an appropriate clinical dose would probably be $5 \mathrm{mg}$ or $10 \mathrm{mg}$ once daily. 


\subsection{Esaxerenone}

Esaxerenone (CS-3150; (5S)-1-(2-hydroxyethyl)-4-methyl- $N$-[4-(methylsulfonyl)phenyl]5-[2-(trifluoromethyl)phenyl]- $1 \mathrm{H}$-pyrrole-3-carboxamide) is a selective and highly potent MRA [87]. Its structure is based on the dihydropyridine calcium antagonist. It is rapidly absorbed, has a long elimination half-life (around 20-30 h) and a dose proportional exposure $[108,109]$. Quantitative whole-body autoradioluminography in rats showed that it is widely distributed to the whole body, with a similar distribution to the heart and the kidneys and with a low distribution to the central nervous system $[104,110]$. Serious adverse events are rare, with the most common being hyperkalemia [111]. Moderate renal impairment (eGFR 30-60 mL/min $/ 1.73 \mathrm{~m}^{2}$ ) and mild or moderate hepatic impairment (Child-Pugh A or B) do not alter esaxerenone's pharmacokinetics in a clinically significant way. However, the effect of severe cases of renal or hepatic impairment on pharmacokinetics is still unknown [111]. Esaxerenone has been mostly investigated in Japan and in 2019 it there received marketing approval as an antihypertensive agent [111]. It is available as $1.25 \mathrm{mg}, 2.5 \mathrm{mg}$ and $5 \mathrm{mg}$ tablets, with the recommended dosage being $2.5 \mathrm{mg}$ once daily. If this is insufficient, the dosage can be increased to $5 \mathrm{mg}$.

Before approval as an antihypertensive drug, two important clinical trials were performed. The first one was a phase 2, multicenter, randomized, double-blind, placebocontrolled, open-label comparator study in Japanese patients with arterial hypertension [112]. After 12 weeks of treatment, esaxerenone was shown to be an effective and tolerable treatment. The same proved to be true in a similar phase 3 study and later also in hypertensive patients with moderate kidney dysfunction $[113,114]$. Until now, esaxerenone has not been studied for other indications, except DKD.

\section{Esaxerenone and DKD}

In kidney disease, esaxerenone first showed promise by reducing proteinuria and kidney injury in rats [115-117]. Bhuyian et al. were the first to study the effect of esaxerenone in mice with DKD [118]. They found that esaxerenone or spironolactone reduced blood pressure to a similar degree, but esaxerenone caused a greater decrease of albuminuria, glomerular injury, tubulointerstitial fibrosis and renal inflammation than spironolactone. This was associated with a decrease in renal oxidative stress. In another study on diabetic mice, Arai et al. found that the renoprotective effects of esaxerenone could be independent of its antihypertensive effect [119].

A study in Japanese patients with arterial hypertension, type $2 \mathrm{DM}$ and albuminuria (UACR 30-999 mg/g) was performed by Itoh et al. [120]. Fifty-one patients received esaxerenone for 12 weeks in a gradually higher dose as an add-on therapy to a RAS inhibitor. Esaxerenone had an additional antihypertensive effect and it significantly reduced albuminuria. The risk of hyperkalemia was made low by adjusting the dose to the patient's serum potassium level, kidney function and blood pressure. A phase $2 \mathrm{~b}$ trial in Japanese patients with type $2 \mathrm{DM}$ and albuminuria was also performed by Ito et al. [121]. It was a multicenter, randomized, double-blind, placebo-controlled trial. They included 365 hypertensive or normotensive patients with type $2 \mathrm{DM}$ and albuminuria (UACR $\geq 45$ to $<300 \mathrm{mg} / \mathrm{g}$ ). All patients had an eGFR $\geq 30 \mathrm{~mL} / \mathrm{min} / 1.73 \mathrm{~m}^{2}$ and were treated with a RAS inhibitor. They received esaxerenone or placebo for 12 weeks. Esaxerenone treatment significantly reduced UACR (38-56\%) in comparison to placebo. The most common adverse event was hyperkalemia, which was dose-proportional. Another phase 3 trial in Japanese type 2 DM patients with albuminuria (Esaxerenone in Diabetic Nephropathy (ESAX-DN) study) followed [122]. In total, 455 patients received esaxerenone or placebo for 52 weeks. Esaxerenone was associated with a $>30 \%$ reduction in UACR in about $70 \%$ of patients. UACR returned to $<30 \mathrm{mg} / \mathrm{g}$ in $22 \%$ of patients and there was a $76 \%$ reduction in hazard of transition to UACR $\geq 300 \mathrm{mg} / \mathrm{g}$. Compared to placebo, more patients in the esaxerenone group had a serum potassium level $\geq 6.0$ or $\geq 5.5 \mathrm{mEq} / \mathrm{L}$ on two successive measurements. Ten $(4 \%)$ patients in the esaxerenone and one $(1 \%)$ in the placebo group stopped treatment 
because of hyperkalemia. Hyperkalemia was asymptomatic and resolved after dosage reduction or treatment discontinuation.

\subsection{Finerenone}

Finerenone (BAY 94-8862; (4S)-4-(4-cyano-2-methoxyphenyl)-5-ethoxy-2,8-dimethyl1,4-dihydro-1,6-naphthyridine-3-carboxamide) is a potent, highly selective, full antagonist of the MR [60]. In contrast with spironolactone and eplerenone, which bind to the ligand domain of the MR, finerenone induces a conformational change within the MR complex, thereby changing the stability and nuclear translocation of the receptor [14]. Structurally, it is a dihydropyridine derivative but it does not have pronounced activity at the L-type calcium channel [61]. It has a half-life of $2 \mathrm{~h}$ and no active metabolites [60]. Finerenone is less lipophilic and has greater polarity than steroidal MRA [88]. Therefore, it is less capable of traversing the blood-brain barrier and interfering with MR in the central nervous system [15]. These qualities are believed to have a significant role in the control of blood pressure [88]. Based on quantitative whole-body autoradiography in rodents, it reaches the same concentration in the kidneys and the heart [60]. Finerenone can also cause hyperkalemia, but according to current studies, it occurs in a significantly lower proportion than steroidal MRA [123]. Finerenone has been used in clinical research in doses from $1.25 \mathrm{mg}$ to $20 \mathrm{mg}$ once daily, although in the latest two clinical trials they used $10 \mathrm{mg}$ or $20 \mathrm{mg}$ once daily depending on eGFR.

Animal studies showed that finerenone has anti-inflammatory and anti-fibrotic effects and consequently beneficial cardiorenal effects [124-127]. Therefore, clinical trials followed. The minerAlocorticoid Receptor antagonist Tolerability Study (ARTS) was a phase 2a clinical trial that assessed the safety and tolerability of finerenone in patients with heart failure with reduced ejection fraction and mild or moderate chronic kidney disease [128]. Finerenone $5-10 \mathrm{mg} /$ day was at least as effective as spironolactone $25 \mathrm{mg}$ or $50 \mathrm{mg} /$ day in decreasing biomarkers of hemodynamic stress with lower incidences of hyperkalemia and worsening renal function. A phase $2 \mathrm{~b}$, randomized, double-blind trial, minerAlocorticoid Receptor antagonist Tolerability Study-Heart Failure (ARTS-HF) followed [129]. In this study, 1066 patients with type $2 \mathrm{DM}$ and/or chronic kidney disease, who presented in emergency departments with worsening chronic heart failure with reduced ejection fraction were randomized. They received oral, once-daily finerenone or eplerenone for 90 days. Finerenone was well tolerated and induced a 30\% or greater decrease in $\mathrm{N}$-terminal pro-brain natriuretic peptide (NT-proBNP) levels in a similar proportion of patients to eplerenone. The composite endpoint of death from any cause, cardiovascular hospitalization or emergency presentation for worsening heart failure occurred less frequently with finerenone compared to eplerenone, also with a smaller mean increase in serum potassium [130].

\section{Finerenone and DKD}

The minerAlocorticoid Receptor antagonist Tolerability Study-Diabetic Nephropathy (ARTS-DN) was a randomized, double-blind, placebo-controlled, phase $2 \mathrm{~b}$ study on 823 type 2 DM patients with albuminuria (UACR $\geq 30 \mathrm{mg} / \mathrm{g}$ ), an eGFR higher than $30 \mathrm{~mL} / \mathrm{min} / 1.73 \mathrm{~m}^{2}$, being treated with at least the minimum recommended dosage of a RAS inhibitor before the screening visit and with a serum potassium concentration $\leq 4.8 \mathrm{mmol} / \mathrm{L}$ [131]. They received different doses of oral finerenone once daily or placebo for 90 days. Finerenone demonstrated a dose-dependent reduction in UACR. Hyperkalemia and subsequent discontinuation of finerenone occurred in $1.8 \%$, compared with no cases in the placebo group. There were no differences in the incidence of eGFR decrease of $\geq 30 \%$ or incidences of adverse and serious adverse events between the placebo and finerenone groups. Additionally, finerenone did not affect glycated hemoglobin (HbA1c) levels [130]. Since the abovementioned study was of shorter duration and since UACR is not a surrogate marker of renal outcome, an upgraded study, FIDELIO-DKD (FInerenone in reducing kiDnEy faiLure and dIsease prOgression in Diabetic Kidney Disease), followed [132]. This was a phase 3 study 
that included 5734 patients with chronic kidney disease and type $2 \mathrm{DM}$ and followed them for a median of 2.6 years. Chronic kidney disease was defined according to one of two sets of criteria: UACR $30-300 \mathrm{mg} / \mathrm{g}$, eGFR $25-60 \mathrm{~mL} / \mathrm{min} / 1.73 \mathrm{~m}^{2}$ and a history of diabetic retinopathy or UACR $300-5000 \mathrm{mg} / \mathrm{g}$ and eGFR $25-75 \mathrm{~mL} / \mathrm{min} / 1.73 \mathrm{~m}^{2}$. All patients were treated with a RAS inhibitor at the maximum dose on the manufacturer's label that did not cause unacceptable side effects and they were required to have a serum potassium level $\leq 4.8 \mathrm{mmol} / \mathrm{L}$. In the study they found that finerenone lowered the risk of primary (kidney failure, a sustained decrease of $\geq 40 \%$ in the eGFR from baseline or death from renal causes) and secondary outcome events (death from cardiovascular causes, nonfatal myocardial infarction, nonfatal stroke or hospitalization for heart failure) in comparison to placebo. Hyperkalemia was more common in the finerenone group, but discontinuation of the trial due to it was uncommon (2.3\%). An additional subgroup analysis of these data showed that finerenone lowered the incidence of the composite cardiovascular outcome independent of preexisting cardiovascular diseases [133]. Another big phase 3 clinical trial was FIGARO-DKD (FInerenone in reducinG cArdiovascular moRtality and mOrbidity in Diabetic Kidney Disease), that investigated the role of finerenone in reducing major cardiovascular events, with slowing DKD progression as a prespecified secondary endpoint $[15,134]$. It was a randomized, double-blind, placebo-controlled trial. They randomized 7437 patients with an eGFR $\geq 25 \mathrm{~mL} / \mathrm{min} / 1.73 \mathrm{~m}^{2}$ and UACR $30-5000 \mathrm{mg} / \mathrm{g}$ to therapy with finerenone or placebo. The primary endpoint was the composite of time to cardiovascular death or non-fatal cardiovascular event (myocardial infarction, stroke or hospitalization for heart failure). A main secondary endpoint was the composite of time to kidney failure, a sustained reduction of eGFR of $\geq 40 \%$ or renal death. Other secondary endpoints were time to all-cause mortality, all-cause hospitalization, UACR change from baseline to month 4 and a composite endpoint of time to first occurrence of kidney failure or sustained decrease of eGFR $\geq 57 \%$ from baseline over at least 4 weeks or renal death. The trial was completed, but the results are not yet published. In May 2021, only a special press release announced that the primary endpoint of the study was reached [135].

The latest meta-analysis, including randomized, controlled trials on the addition of MRA to RAS inhibitors in DKD, was published in 2019 [84]. The authors performed a subgroup analysis that suggested a lower relative risk of hyperkalemia with finerenone than with eplerenone or spironolactone. However, a limitation is that for finerenone only the first published study (ARTS-DN) was used for this analysis.

\section{Conclusions}

MRA have a role in DKD in lowering albuminuria. Hard outcomes such as kidney disease progression, cardiovascular events and mortality data are missing for all MRA except finerenone. The use of steroidal MRA in DKD has been limited by its side effects, especially hyperkalemia. Perhaps with sufficient attention to diet, ACE inhibitor/ARB use, potassium binder use, kidney function, regular serum potassium controls and thorough dose adjustment their use could be more widespread. With the advent of non-steroidal MRA that cause less hyperkalemia, their use in DKD might even become everyday clinical practice. Table 1 summarizes an overview of MRA used in everyday clinical practice and the latest clinical research. MRA still represent an exciting and growing research field. The goal is to find a selective antagonist with a tissue and function-specific mode of action. In the future, coregulators of MR may represent the next generation of MR modulators. 
Table 1. Overview of mineralocorticoid receptor antagonists (MRA) used in everyday clinical practice and latest clinical research.

\begin{tabular}{|c|c|c|c|c|c|}
\hline & $\begin{array}{l}\text { Spironolactone } \\
\text { (SC-9420) }\end{array}$ & $\begin{array}{l}\text { Eplerenone } \\
\text { (CGP-30083) }\end{array}$ & $\begin{array}{l}\text { Apararenone } \\
\text { (MT-3995) }\end{array}$ & $\begin{array}{l}\text { Esaxerenone } \\
(\mathrm{CS}-3150)\end{array}$ & $\begin{array}{l}\text { Finerenone } \\
\text { (BAY 94-8862) }\end{array}$ \\
\hline Type of MRA & Steroidal & Steroidal & $\begin{array}{l}\text { Non-steroidal } \\
\text { (benzoxazinone } \\
\text { derivative) }\end{array}$ & $\begin{array}{c}\text { Non-steroidal } \\
\text { (dihydropyridine } \\
\text { derivative) }\end{array}$ & $\begin{array}{c}\text { Non-steroidal } \\
\text { (dihydropyridine } \\
\text { derivative) }\end{array}$ \\
\hline Potency & ++ & + & + & +++ & +++ \\
\hline Selectivity & + & ++ & +++ & +++ & +++ \\
\hline Half-life & $1-2 \mathrm{~h}$ & $4-6 \mathrm{~h}$ & $\begin{array}{l}\text { Long (approximately } \\
\qquad 250-300 \mathrm{~h})\end{array}$ & $20-30 \mathrm{~h}$ & $2 \mathrm{~h}$ \\
\hline Major metabolite(s) & $\begin{array}{l}\text { 7 } \alpha \text {-thiomethyl- } \\
\text { spironolactone } \\
\text { Canrenone } \\
\text { (half-life: } 18-24 \mathrm{~h} \text { ) }\end{array}$ & None & 1118174 & M4, M11, M1 & None \\
\hline Tissue distribution * & $\begin{array}{l}\quad 6 \times \text { higher } \\
\text { concentration in the } \\
\text { kidneys than in the } \\
\text { heart }\end{array}$ & $\begin{array}{l}3 \times \text { higher } \\
\text { concentration in the } \\
\text { kidneys than in } \\
\text { the heart }\end{array}$ & Unknown & $\begin{array}{l}\text { Same concentration } \\
\text { in the kidneys and } \\
\text { the heart, low } \\
\text { concentration in the } \\
\text { CNS }\end{array}$ & $\begin{array}{c}\text { Same concentration } \\
\text { in the kidneys and } \\
\text { the heart }\end{array}$ \\
\hline Approved for use & $\begin{array}{c}\text { Edema } \\
\text { AH } \\
\text { Primary } \\
\text { hyperaldosteronism }\end{array}$ & $\begin{array}{c}\mathrm{AH} \\
\text { Symptomatic HFrEF } \\
\text { after AMI }\end{array}$ & / & AH (Japan) & / \\
\hline Dosing & $\begin{array}{c}\text { Ascites due to } \\
\text { cirrhosis: 100-400 } \\
\text { mg/day } \\
\text { Symptomatic HFrEF: } \\
12.5-50 \mathrm{mg} / \text { day } \\
\text { AH: } 25-100 \mathrm{mg} \text { /day } \\
\text { Primary } \\
\text { hyperaldosteronism: } \\
\text { 12.5-400 mg/day }\end{array}$ & $\begin{array}{c}\text { AH: } 50 \text { mg 1-2×/day } \\
\text { Symptomatic HFrEF } \\
\text { after AMI: } 25-50 \\
\text { mg/day }\end{array}$ & $\begin{array}{l}\text { In research: } 5 \mathrm{mg} \text { or } \\
10 \mathrm{mg} / \mathrm{day}\end{array}$ & $2.5-5 \mathrm{mg} /$ day & $\begin{array}{l}\text { In research: } 10 \mathrm{mg} \text { or } \\
20 \mathrm{mg} / \text { day }\end{array}$ \\
\hline Side effects & $\begin{array}{c}\text { Hormonal } \\
\text { (gynecomastia, } \\
\text { impotence, menstrual } \\
\text { irregularities) } \\
\text { Hyperkalemia }\end{array}$ & Hyperkalemia & Unknown & Hyperkalemia & Hyperkalemia \\
\hline $\begin{array}{l}\text { Important clinical } \\
\text { studies in } \\
\text { cardiovascular } \\
\text { medicine }\end{array}$ & $\begin{array}{l}\text { RALES study [63] } \\
\text { TOPCAT trial [64] } \\
\text { ALBATROSS } \\
\text { trial [65] }\end{array}$ & $\begin{array}{c}\text { Weinberger et al. [92] } \\
\text { EPHESUS [93] } \\
\text { EMPHASIS-HF [94] } \\
\text { Montalescot et al. } \\
\text { [97] }\end{array}$ & None & $\begin{array}{l}\text { Ito et al. [112] } \\
\text { Ito et al. [113] }\end{array}$ & $\begin{array}{c}\text { ARTS [128] } \\
\text { ARTS-HF [129] }\end{array}$ \\
\hline $\begin{array}{l}\text { Important clinical } \\
\text { studies in diabetic } \\
\text { kidney disease }\end{array}$ & $\begin{array}{c}\text { Rossing et al. [75] } \\
\text { Schojedt et al. [76] } \\
\text { van den Mairacker } \\
\text { et al. [77] } \\
\text { Mehdi et al. [80] } \\
\text { Hou et al. [83] } \\
\text { Zou et al. [84] }\end{array}$ & $\begin{array}{l}\text { Epstein et al. [102] } \\
\text { Epstein et al. [103] }\end{array}$ & Wada et al. [107] & $\begin{array}{l}\text { Itoh et al. [120] } \\
\text { Ito et al. [121] } \\
\text { ESAX-DN [122] }\end{array}$ & $\begin{array}{l}\text { ARTS-DN [131] } \\
\text { FIDELIO-DKD [132] } \\
\text { FIGARO-DKD [134] }\end{array}$ \\
\hline
\end{tabular}

Legend: * Based on quantitative whole-body autoradiography in rodents; AH-arterial hypertension, AMI-acute myocardial infarction, CNS - central nervous system, HFrEF-heart failure with reduced ejection fraction, / = not approved for use.

Author Contributions: Conceptualization, N.V.H., R.H., S.B., R.E.; writing-original draft preparation, N.V.H.; writing-review and editing, N.V.H., R.H., S.B., R.E., N.P., T.P. All authors have read and agreed to the published version of the manuscript.

Funding: This research received no external funding.

Institutional Review Board Statement: Not applicable.

Informed Consent Statement: Not applicable. 
Data Availability Statement: No new data were created or analyzed in this study. Data sharing is not applicable to this article.

Conflicts of Interest: The authors declare no conflict of interest.

\section{References}

1. International Diabetes Federation. IDF Diabetes Atlas, 9th ed.; IDF: Brussels, Belgium, 2019.

2. Koye, D.N.; Magliano, D.J.; Nelson, R.G.; Pavkov, M.E. The Global Epidemiology of Diabetes and Kidney Disease. Adv. Chronic Kidney Dis. 2018, 25, 121-132. [CrossRef] [PubMed]

3. Einarson, T.R.; Acs, A.; Ludwig, C.; Panton, U.H. Prevalence of cardiovascular disease in type 2 diabetes: A systematic literature review of scientific evidence from across the world in 2007-2017. Cardiovasc. Diabetol. 2018, 17, 83. [CrossRef]

4. Tancredi, M.; Rosengren, A.; Svensson, A.M.; Kosiborod, M.; Pivodic, A.; Gudbjörnsdottir, S.; Wedel, H.; Clements, M.; Dahlqvist, S.; Lind, M. Excess Mortality among Persons with Type 2 Diabetes. N. Engl. J. Med. 2015, 373, 1720-1732. [CrossRef] [PubMed]

5. Afkarian, M.; Sachs, M.C.; Kestenbaum, B.; Hirsch, I.B.; Tuttle, K.R.; Himmelfarb, J.; de Boer, I.H. Kidney disease and increased mortality risk in type 2 diabetes. J. Am. Soc. Nephrol. 2013, 24, 302-308. [CrossRef] [PubMed]

6. Salinero-Fort, M.; San Andrés-Rebollo, F.J.; de Burgos-Lunar, C.; Abánades-Herranz, J.C.; Carrillo-de-Santa-Pau, E.; ChicoMoraleja, R.M.; Jiménez-García, R.; López-de-Andrés, A.; Gómez-Campelo, P. Cardiovascular and all-cause mortality in patients with type 2 diabetes mellitus in the MADIABETES Cohort Study: Association with chronic kidney disease. J. Diabetes Complicat. 2016, 30, 227-236. [CrossRef]

7. Penno, G.; Solini, A.; Bonora, E.; Orsi, E.; Fondelli, C.; Zerbini, G.; Trevisan, R.; Vedovato, M.; Cavalot, F.; Laviola, L.; et al. Defining the contribution of chronic kidney disease to all-cause mortality in patients with type 2 diabetes: The Renal Insufficiency And Cardiovascular Events (RIACE) Italian Multicenter Study. Acta Diabetol. 2018, 55, 603-612. [CrossRef] [PubMed]

8. Wen, C.P.; Chang, C.H.; Tsai, M.K.; Lee, J.H.; Lu, P.J.; Tsai, S.P.; Wen, C.; Chen, C.H.; Kao, C.W.; Tsao, C.K.; et al. Diabetes with early kidney involvement may shorten life expectancy by 16 years. Kidney Int. 2017, 92, 388-396. [CrossRef] [PubMed]

9. Bommer, C.; Heesemann, E.; Sagalova, V.; Manne-Goehler, J.; Atun, R.; Bärnighausen, T.; Vollmer, S. The global economic burden of diabetes in adults aged 20-79 years: A cost-of-illness study. Lancet Diabetes Endocrinol. 2017, 5, 423-430. [CrossRef]

10. Einarson, T.R.; Acs, A.; Ludwig, C.; Panton, U.H. Economic Burden of Cardiovascular Disease in Type 2 Diabetes: A Systematic Review. Value Health 2018, 21, 881-890. [CrossRef]

11. Coresh, J.; Heerspink, H.J.L.; Sang, Y.; Matsushita, K.; Arnlov, J.; Astor, B.C.; Black, C.; Brunskill, N.J.; Carrero, J.J.; Feldman, H.I.; et al. Change in albuminuria and subsequent risk of end-stage kidney disease: An individual participant-level consortium meta-analysis of observational studies. Lancet Diabetes Endocrinol. 2019, 7, 115-127. [CrossRef]

12. Levey, A.S.; de Jong, P.E.; Coresh, J.; El Nahas, M.; Astor, B.C.; Matsushita, K.; Gansevoort, R.T.; Kasiske, B.L.; Eckardt, K.U. The definition, classification, and prognosis of chronic kidney disease: A KDIGO Controversies Conference report. Kidney Int. 2011, 80, 17-28. [CrossRef] [PubMed]

13. Alicic, R.Z.; Rooney, M.T.; Tuttle, K.R. Diabetic Kidney Disease: Challenges, Progress, and Possibilities. Clin. J. Am. Soc. Nephrol. 2017, 12, 2032-2045. [CrossRef] [PubMed]

14. Muskiet, M.H.A.; Wheeler, D.C.; Heerspink, H.J.L. New pharmacological strategies for protecting kidney function in type 2 diabetes. Lancet Diabetes Endocrinol. 2019, 7, 397-412. [CrossRef]

15. Al Dhaybi, O.; Bakris, G.L. Non-steroidal mineralocorticoid antagonists: Prospects for renoprotection in diabetic kidney disease. Diabetes Obes. Metab. 2020, 22 (Suppl. 1), 69-76. [CrossRef]

16. Shunan, F.; Jiqing, Y.; Xue, D. Effects of angiotensin-converting enzyme inhibitors and angiotensin receptor blockers on cardiovascular events in patients with diabetes and overt nephropathy: A meta-analysis of randomised controlled trials. J. Renin Angiotensin Aldosterone Syst. 2018, 19, 1470320318803495. [CrossRef] [PubMed]

17. Salah, H.M.; Al'Aref, S.J.; Khan, M.S.; Al-Hawwas, M.; Vallurupalli, S.; Mehta, J.L.; Mounsey, J.P.; Greene, S.J.; McGuire, D.K.; Lopes, R.D.; et al. Effect of sodium-glucose cotransporter 2 inhibitors on cardiovascular and kidney outcomes-Systematic review and meta-analysis of randomized placebo-controlled trials. Am. Heart J. 2021, 232, 10-22. [CrossRef]

18. Heerspink, H.J.L.; Stefánsson, B.V.; Correa-Rotter, R.; Chertow, G.M.; Greene, T.; Hou, F.F.; Mann, J.F.E.; McMurray, J.J.V.; Lindberg, M.; Rossing, P.; et al. Dapagliflozin in Patients with Chronic Kidney Disease. N. Engl. J. Med. 2020, 383, 1436-1446. [CrossRef] [PubMed]

19. Wanner, C.; Inzucchi, S.E.; Lachin, J.M.; Fitchett, D.; von Eynatten, M.; Mattheus, M.; Johansen, O.E.; Woerle, H.J.; Broedl, U.C.; Zinman, B. Empagliflozin and Progression of Kidney Disease in Type 2 Diabetes. N. Engl. J. Med. 2016, 375, 323-334. [CrossRef] [PubMed]

20. Perkovic, V.; Jardine, M.J.; Neal, B.; Bompoint, S.; Heerspink, H.J.L.; Charytan, D.M.; Edwards, R.; Agarwal, R.; Bakris, G.; Bull, S.; et al. Canagliflozin and Renal Outcomes in Type 2 Diabetes and Nephropathy. N. Engl. J. Med. 2019, 380, $2295-2306$. [CrossRef] [PubMed]

21. Brenner, S.; Wanner, C. Diabetic Kidney Disease-How to Protect the Kidney? Dtsch. Med. Wochenschr. 2019, 144, 710-714. [CrossRef] [PubMed]

22. Wanner, C.; Cooper, M.E.; Johansen, O.E.; Toto, R.; Rosenstock, J.; McGuire, D.K.; Kahn, S.E.; Pfarr, E.; Schnaidt, S.; von Eynatten, M.; et al. Effect of linagliptin versus placebo on cardiovascular and kidney outcomes in nephrotic-range proteinuria and type 2 diabetes: The CARMELINA randomized controlled trial. Clin. Kidney J. 2021, 14, 226-236. [CrossRef] 
23. Bae, J.H.; Kim, S.; Park, E.G.; Kim, S.G.; Hahn, S.; Kim, N.H. Effects of Dipeptidyl Peptidase-4 Inhibitors on Renal Outcomes in Patients with Type 2 Diabetes: A Systematic Review and Meta-Analysis. Endocrinol. Metab. 2019, 34, 80-92. [CrossRef] [PubMed]

24. Hartman, R.E.; Rao, P.S.S.; Churchwell, M.D.; Lewis, S.J. Novel therapeutic agents for the treatment of diabetic kidney disease. Expert Opin. Investig. Drugs 2020, 29, 1277-1293. [CrossRef]

25. Heerspink, H.J.L.; Parving, H.H.; Andress, D.L.; Bakris, G.; Correa-Rotter, R.; Hou, F.F.; Kitzman, D.W.; Kohan, D.; Makino, H.; McMurray, J.J.V.; et al. Atrasentan and renal events in patients with type 2 diabetes and chronic kidney disease (SONAR): A double-blind, randomised, placebo-controlled trial. Lancet 2019, 393, 1937-1947. [CrossRef]

26. Tuttle, K.R.; Brosius, F.C., 3rd; Adler, S.G.; Kretzler, M.; Mehta, R.L.; Tumlin, J.A.; Tanaka, Y.; Haneda, M.; Liu, J.; Silk, M.E.; et al. JAK1/JAK2 inhibition by baricitinib in diabetic kidney disease: Results from a Phase 2 randomized controlled clinical trial. Nephrol. Dial. Transplant. 2018, 33, 1950-1959. [CrossRef]

27. Srivastava, S.P.; Goodwin, J.E.; Kanasaki, K.; Koya, D. Metabolic reprogramming by N-acetyl-seryl-aspartyl-lysyl-proline protects against diabetic kidney disease. Br. J. Pharmacol. 2020, 177, 3691-3711. [CrossRef] [PubMed]

28. Kanasaki, K. N-acetyl-seryl-aspartyl-lysyl-proline is a valuable endogenous antifibrotic peptide for kidney fibrosis in diabetes: An update and translational aspects. J. Diabetes Investig. 2020, 11, 516-526. [CrossRef] [PubMed]

29. Srivastava, S.P.; Zhou, H.; Setia, O.; Liu, B.; Kanasaki, K.; Koya, D.; Dardik, A.; Fernandez-Hernando, C.; Goodwin, J. Loss of endothelial glucocorticoid receptor accelerates diabetic nephropathy. Nat. Commun. 2021, 12, 2368. [CrossRef]

30. Epstein, M. Aldosterone and Mineralocorticoid Receptor Signaling as Determinants of Cardiovascular and Renal Injury: From Hans Selye to the Present. Am. J. Nephrol. 2021, 52, 209-216. [CrossRef] [PubMed]

31. Taves, M.D.; Gomez-Sanchez, C.E.; Soma, K.K. Extra-adrenal glucocorticoids and mineralocorticoids: Evidence for local synthesis, regulation, and function. Am. J. Physiol. Endocrinol. Metab. 2011, 301, E11-E24. [CrossRef]

32. Selye, H. Production of Nephrosclerosis by Overdosage with Desoxycorticosterone Acetate. Can. Med. Assoc. J. 1942, 47, 515-519. [PubMed]

33. Selye, H.; Hall, C.E.; Rowley, E.M. Malignant Hypertension Produced by Treatment with Desoxycorticosterone Acetate and Sodium Chloride. Can. Med. Assoc. J. 1943, 49, 88-92. [PubMed]

34. Selye, H. Protection by a steroid-spirolactone against certain types of cardiac necroses. Proc. Soc. Exp. Biol. Med. 1960, 104, 212-213. [CrossRef] [PubMed]

35. Brilla, C.G.; Pick, R.; Tan, L.B.; Janicki, J.S.; Weber, K.T. Remodeling of the rat right and left ventricles in experimental hypertension. Circ. Res. 1990, 67, 1355-1364. [CrossRef] [PubMed]

36. Brilla, C.G.; Weber, K.T. Mineralocorticoid excess, dietary sodium, and myocardial fibrosis. J. Lab. Clin. Med. 1992, 120, 893-901. [PubMed]

37. Brilla, C.G.; Weber, K.T. Reactive and reparative myocardial fibrosis in arterial hypertension in the rat. Cardiovasc. Res. 1992, 26, 671-677. [CrossRef] [PubMed]

38. Gomez-Sanchez, E.; Gomez-Sanchez, C.E. The multifaceted mineralocorticoid receptor. Compr. Physiol. 2014, 4, 965-994. [CrossRef] [PubMed]

39. Agarwal, A.; Cheung, A.K. Mineralocorticoid Receptor Antagonists in ESKD. Clin. J. Am. Soc. Nephrol. 2020, 15, 1047-1049. [CrossRef]

40. Cheng, L.; Poulsen, S.B.; Wu, Q.; Esteva-Font, C.; Olesen, E.T.B.; Peng, L.; Olde, B.; Leeb-Lundberg, L.M.F.; Pisitkun, T.; Rieg, T.; et al. Rapid Aldosterone-Mediated Signaling in the DCT Increases Activity of the Thiazide-Sensitive NaCl Cotransporter. J. Am. Soc. Nephrol. 2019, 30, 1454-1470. [CrossRef]

41. Funder, J.W. Aldosterone and Mineralocorticoid Receptors-Physiology and Pathophysiology. Int. J. Mol. Sci. 2017, 18, 1032. [CrossRef] [PubMed]

42. Funder, J.W. Aldosterone Research: 65 Years, and Counting. Vitam. Horm. 2019, 109, 1-15. [CrossRef]

43. Gomez-Sanchez, E.P. Third-generation Mineralocorticoid Receptor Antagonists: Why Do We Need a Fourth? J. Cardiovasc. Pharmacol. 2016, 67, 26-38. [CrossRef] [PubMed]

44. Ulick, S. Cortisol as mineralocorticoid. J. Clin. Endocrinol. Metab. 1996, 81, 1307-1308. [CrossRef]

45. Messaoudi, S.; Azibani, F.; Delcayre, C.; Jaisser, F. Aldosterone, mineralocorticoid receptor, and heart failure. Mol. Cell Endocrinol. 2012, 350, 266-272. [CrossRef]

46. Agarwal, R.; Kolkhof, P.; Bakris, G.; Bauersachs, J.; Haller, H.; Wada, T.; Zannad, F. Steroidal and non-steroidal mineralocorticoid receptor antagonists in cardiorenal medicine. Eur. Heart J. 2021, 42, 152-161. [CrossRef] [PubMed]

47. Sztechman, D.; Czarzasta, K.; Cudnoch-Jedrzejewska, A.; Szczepanska-Sadowska, E.; Zera, T. Aldosterone and mineralocorticoid receptors in regulation of the cardiovascular system and pathological remodelling of the heart and arteries. J. Physiol. Pharmacol. 2018, 69. [CrossRef]

48. Bramlage, P.; Swift, S.L.; Thoenes, M.; Minguet, J.; Ferrero, C.; Schmieder, R.E. Non-steroidal mineralocorticoid receptor antagonism for the treatment of cardiovascular and renal disease. Eur. J. Heart Fail. 2017, 19, 811. [CrossRef] [PubMed]

49. Cannavo, A.; Bencivenga, L.; Liccardo, D.; Elia, A.; Marzano, F.; Gambino, G.; D’Amico, M.L.; Perna, C.; Ferrara, N.; Rengo, G.; et al. Aldosterone and Mineralocorticoid Receptor System in Cardiovascular Physiology and Pathophysiology. Oxid. Med. Cell Longev. 2018, 2018, 1204598. [CrossRef]

50. Buonafine, M.; Bonnard, B.; Jaisser, F. Mineralocorticoid Receptor and Cardiovascular Disease. Am. J. Hypertens. 2018, 31, 1165-1174. [CrossRef] 
51. Capelli, I.; Gasperoni, L.; Ruggeri, M.; Donati, G.; Baraldi, O.; Sorrenti, G.; Caletti, M.T.; Aiello, V.; Cianciolo, G.; La Manna, G. New mineralocorticoid receptor antagonists: Update on their use in chronic kidney disease and heart failure. J. Nephrol. 2020, 33, 37-48. [CrossRef]

52. Thuzar, M.; Stowasser, M. The mineralocorticoid receptor-an emerging player in metabolic syndrome? J. Hum. Hypertens. 2021, 35, 117-123. [CrossRef] [PubMed]

53. Kolkhof, P.; Bärfacker, L. 30 YEARS OF THE MINERALOCORTICOID RECEPTOR: Mineralocorticoid receptor antagonists: 60 years of research and development. J. Endocrinol. 2017, 234, T125-T140. [CrossRef] [PubMed]

54. de Gasparo, M.; Whitebread, S.E.; Preiswerk, G.; Jeunemaître, X.; Corvol, P.; Ménard, J. Antialdosterones: Incidence and prevention of sexual side effects. J. Steroid. Biochem. 1989, 32, 223-227. [CrossRef]

55. Navaneethan, S.D.; Nigwekar, S.U.; Sehgal, A.R.; Strippoli, G.F. Aldosterone antagonists for preventing the progression of chronic kidney disease: A systematic review and meta-analysis. Clin. J. Am. Soc. Nephrol. 2009, 4, 542-551. [CrossRef] [PubMed]

56. Alexandrou, M.E.; Papagianni, A.; Tsapas, A.; Loutradis, C.; Boutou, A.; Piperidou, A.; Papadopoulou, D.; Ruilope, L.; Bakris, G.; Sarafidis, P. Effects of mineralocorticoid receptor antagonists in proteinuric kidney disease: A systematic review and meta-analysis of randomized controlled trials. J. Hypertens. 2019, 37, 2307-2324. [CrossRef]

57. Heerspink, H.J.L.; Greene, T.; Tighiouart, H.; Gansevoort, R.T.; Coresh, J.; Simon, A.L.; Chan, T.M.; Hou, F.F.; Lewis, J.B.; Locatelli, F.; et al. Change in albuminuria as a surrogate endpoint for progression of kidney disease: A meta-analysis of treatment effects in randomised clinical trials. Lancet Diabetes Endocrinol. 2019, 7, 128-139. [CrossRef]

58. Gerstein, H.C.; Mann, J.F.; Yi, Q.; Zinman, B.; Dinneen, S.F.; Hoogwerf, B.; Hallé, J.P.; Young, J.; Rashkow, A.; Joyce, C.; et al. Albuminuria and risk of cardiovascular events, death, and heart failure in diabetic and nondiabetic individuals. JAMA 2001, 286, 421-426. [CrossRef]

59. Liddle, G.W. Sodium diuresis induced by steroidal antagonists of aldosterone. Science 1957, 126, 1016-1018. [CrossRef] [PubMed]

60. Yang, J.; Young, M.J. Mineralocorticoid receptor antagonists-pharmacodynamics and pharmacokinetic differences. Curr. Opin. Pharmacol. 2016, 27, 78-85. [CrossRef] [PubMed]

61. Kolkhof, P.; Borden, S.A. Molecular pharmacology of the mineralocorticoid receptor: Prospects for novel therapeutics. Mol. Cell Endocrinol. 2012, 350, 310-317. [CrossRef] [PubMed]

62. Highlights of Prescribing Information-Aldactone®(Spironolactone) Tablets, for Oral Use. Available online: https://www. accessdata.fda.gov/drugsatfda_docs/label/2018/012151s075lbl.pdf (accessed on 10 April 2021).

63. Pitt, B.; Zannad, F.; Remme, W.J.; Cody, R.; Castaigne, A.; Perez, A.; Palensky, J.; Wittes, J. The effect of spironolactone on morbidity and mortality in patients with severe heart failure. Randomized Aldactone Evaluation Study Investigators. N. Engl. J. Med. 1999, 341, 709-717. [CrossRef] [PubMed]

64. Pitt, B.; Pfeffer, M.A.; Assmann, S.F.; Boineau, R.; Anand, I.S.; Claggett, B.; Clausell, N.; Desai, A.S.; Diaz, R.; Fleg, J.L.; et al. Spironolactone for heart failure with preserved ejection fraction. N. Engl. J. Med. 2014, 370, 1383-1392. [CrossRef] [PubMed]

65. Beygui, F.; Cayla, G.; Roule, V.; Roubille, F.; Delarche, N.; Silvain, J.; Van Belle, E.; Belle, L.; Galinier, M.; Motreff, P.; et al. Early Aldosterone Blockade in Acute Myocardial Infarction: The ALBATROSS Randomized Clinical Trial. J. Am. Coll. Cardiol. 2016, 67, 1917-1927. [CrossRef]

66. Miric, G.; Dallemagne, C.; Endre, Z.; Margolin, S.; Taylor, S.M.; Brown, L. Reversal of cardiac and renal fibrosis by pirfenidone and spironolactone in streptozotocin-diabetic rats. Br. J. Pharmacol. 2001, 133, 687-694. [CrossRef]

67. Fujisawa, G.; Okada, K.; Muto, S.; Fujita, N.; Itabashi, N.; Kusano, E.; Ishibashi, S. Spironolactone prevents early renal injury in streptozotocin-induced diabetic rats. Kidney Int. 2004, 66, 1493-1502. [CrossRef]

68. Han, S.Y.; Kim, C.H.; Kim, H.S.; Jee, Y.H.; Song, H.K.; Lee, M.H.; Han, K.H.; Kim, H.K.; Kang, Y.S.; Han, J.Y.; et al. Spironolactone prevents diabetic nephropathy through an anti-inflammatory mechanism in type 2 diabetic rats. J. Am. Soc. Nephrol. 2006, 17, 1362-1372. [CrossRef] [PubMed]

69. Yuan, J.; Jia, R.; Bao, Y. Beneficial effects of spironolactone on glomerular injury in streptozotocin-induced diabetic rats. J. Renin Angiotensin Aldosterone Syst 2007, 8, 118-126. [CrossRef]

70. Taira, M.; Toba, H.; Murakami, M.; Iga, I.; Serizawa, R.; Murata, S.; Kobara, M.; Nakata, T. Spironolactone exhibits direct renoprotective effects and inhibits renal renin-angiotensin-aldosterone system in diabetic rats. Eur. J. Pharmacol. 2008, 589, $264-271$. [CrossRef] [PubMed]

71. Pessôa, B.S.; Peixoto, E.B.; Papadimitriou, A.; Lopes de Faria, J.M.; Lopes de Faria, J.B. Spironolactone improves nephropathy by enhancing glucose-6-phosphate dehydrogenase activity and reducing oxidative stress in diabetic hypertensive rat. J. Renin Angiotensin Aldosterone Syst. 2012, 13, 56-66. [CrossRef] [PubMed]

72. Zhou, Q.; Liu, K.; Wu, H.; Chen, L.; Pouranan, V.; Yuan, M.; Xiao, Z.; Peng, W.; Xiang, A.; Tang, R.; et al. Spironolactone rescues Dot1a-Af9-mediated repression of endothelin-1 and improves kidney injury in streptozotocin-induced diabetic rats. PLoS ONE 2012, 7, e47360. [CrossRef] [PubMed]

73. Chrysostomou, A.; Becker, G. Spironolactone in addition to ACE inhibition to reduce proteinuria in patients with chronic renal disease. N. Engl. J. Med. 2001, 345, 925-926. [CrossRef]

74. Sato, A.; Hayashi, K.; Naruse, M.; Saruta, T. Effectiveness of aldosterone blockade in patients with diabetic nephropathy. Hypertension 2003, 41, 64-68. [CrossRef] 
75. Rossing, K.; Schjoedt, K.J.; Smidt, U.M.; Boomsma, F.; Parving, H.H. Beneficial effects of adding spironolactone to recommended antihypertensive treatment in diabetic nephropathy: A randomized, double-masked, cross-over study. Diabetes Care 2005, 28, 2106-2112. [CrossRef] [PubMed]

76. Schjoedt, K.J.; Rossing, K.; Juhl, T.R.; Boomsma, F.; Rossing, P.; Tarnow, L.; Parving, H.H. Beneficial impact of spironolactone in diabetic nephropathy. Kidney Int. 2005, 68, 2829-2836. [CrossRef]

77. van den Meiracker, A.H.; Baggen, R.G.; Pauli, S.; Lindemans, A.; Vulto, A.G.; Poldermans, D.; Boomsma, F. Spironolactone in type 2 diabetic nephropathy: Effects on proteinuria, blood pressure and renal function. J. Hypertens. 2006, 24, 2285-2292. [CrossRef] [PubMed]

78. Takebayashi, K.; Matsumoto, S.; Aso, Y.; Inukai, T. Aldosterone blockade attenuates urinary monocyte chemoattractant protein-1 and oxidative stress in patients with type 2 diabetes complicated by diabetic nephropathy. J. Clin. Endocrinol. Metab. 2006, 91, 2214-2217. [CrossRef]

79. Nielsen, S.E.; Schjoedt, K.J.; Rossing, K.; Persson, F.; Schalkwijk, C.G.; Stehouwer, C.D.; Parving, H.H.; Rossing, P. Levels of NT-proBNP, markers of low-grade inflammation, and endothelial dysfunction during spironolactone treatment in patients with diabetic kidney disease. J. Renin Angiotensin Aldosterone Syst. 2013, 14, 161-166. [CrossRef]

80. Mehdi, U.F.; Adams-Huet, B.; Raskin, P.; Vega, G.L.; Toto, R.D. Addition of angiotensin receptor blockade or mineralocorticoid antagonism to maximal angiotensin-converting enzyme inhibition in diabetic nephropathy. J. Am. Soc. Nephrol. 2009, 20, 2641-2650. [CrossRef]

81. Esteghamati, A.; Noshad, S.; Jarrah, S.; Mousavizadeh, M.; Khoee, S.H.; Nakhjavani, M. Long-term effects of addition of mineralocorticoid receptor antagonist to angiotensin II receptor blocker in patients with diabetic nephropathy: A randomized clinical trial. Nephrol. Dial. Transplant. 2013, 28, 2823-2833. [CrossRef]

82. Makhlough, A.; Kashi, Z.; Akha, O.; Zaboli, E.; Yazdanicharati, J. Effect of spironolactone on diabetic nephropathy compared to the combination of spironolactone and losartan. Nephrourol. Mon. 2014, 6, e12148. [CrossRef] [PubMed]

83. Hou, J.; Xiong, W.; Cao, L.; Wen, X.; Li, A. Spironolactone Add-on for Preventing or Slowing the Progression of Diabetic Nephropathy: A Meta-analysis. Clin. Ther. 2015, 37, 2086-2103.e2010. [CrossRef]

84. Zuo, C.; Xu, G. Efficacy and safety of mineralocorticoid receptor antagonists with ACEI/ARB treatment for diabetic nephropathy: A meta-analysis. Int. J. Clin. Pract 2019, e13413. [CrossRef] [PubMed]

85. Mulder, S.; Perco, P.; Oxlund, C.; Mehdi, U.F.; Hankemeier, T.; Jacobsen, I.A.; Toto, R.; Heerspink, H.J.L.; Pena, M.J. Baseline urinary metabolites predict albuminuria response to spironolactone in type 2 diabetes. Transl. Res. 2020, 222, 17-27. [CrossRef]

86. Tofte, N.; Lindhardt, M.; Adamova, K.; Bakker, S.J.L.; Beige, J.; Beulens, J.W.J.; Birkenfeld, A.L.; Currie, G.; Delles, C.; Dimos, I.; et al. Early detection of diabetic kidney disease by urinary proteomics and subsequent intervention with spironolactone to delay progression (PRIORITY): A prospective observational study and embedded randomised placebo-controlled trial. Lancet Diabetes Endocrinol. 2020, 8, 301-312. [CrossRef]

87. Sueta, D.; Yamamoto, E.; Tsujita, K. Mineralocorticoid Receptor Blockers: Novel Selective Nonsteroidal Mineralocorticoid Receptor Antagonists. Curr. Hypertens. Rep. 2020, 22, 21. [CrossRef]

88. Kolkhof, P.; Nowack, C.; Eitner, F. Nonsteroidal antagonists of the mineralocorticoid receptor. Curr. Opin. Nephrol. Hypertens. 2015, 24, 417-424. [CrossRef] [PubMed]

89. Abuannadi, M.; O’Keefe, J.H. Review article: Eplerenone: An underused medication? J. Cardiovasc. Pharmacol. Ther. 2010, 15, 318-325. [CrossRef] [PubMed]

90. Craft, J. Eplerenone (Inspra), a new aldosterone antagonist for the treatment of systemic hypertension and heart failure. Bayl. Univ. Med. Cent. Proc. 2004, 17, 217-220. [CrossRef] [PubMed]

91. Highlights of Prescribing Information-Inspra®(Eplerenone) Tablets, for Oral Use. Available online: https://www.accessdata.fda. gov /drugsatfda_docs/label/2008/021437s006lbl.pdf (accessed on 12 May 2021).

92. Weinberger, M.H.; Roniker, B.; Krause, S.L.; Weiss, R.J. Eplerenone, a selective aldosterone blocker, in mild-to-moderate hypertension. Am. J. Hypertens. 2002, 15, 709-716. [CrossRef]

93. Pitt, B.; Remme, W.; Zannad, F.; Neaton, J.; Martinez, F.; Roniker, B.; Bittman, R.; Hurley, S.; Kleiman, J.; Gatlin, M. Eplerenone, a selective aldosterone blocker, in patients with left ventricular dysfunction after myocardial infarction. N. Engl. J. Med. 2003, 348, 1309-1321. [CrossRef] [PubMed]

94. Zannad, F.; McMurray, J.J.; Krum, H.; van Veldhuisen, D.J.; Swedberg, K.; Shi, H.; Vincent, J.; Pocock, S.J.; Pitt, B. Eplerenone in patients with systolic heart failure and mild symptoms. N. Engl. J. Med. 2011, 364, 11-21. [CrossRef] [PubMed]

95. Seferovic, P.M.; Pelliccia, F.; Zivkovic, I.; Ristic, A.; Lalic, N.; Seferovic, J.; Simeunovic, D.; Milinkovic, I.; Rosano, G. Mineralocorticoid receptor antagonists, a class beyond spironolactone-Focus on the special pharmacologic properties of eplerenone. Int. J. Cardiol. 2015, 200, 3-7. [CrossRef] [PubMed]

96. Preiss, D.; van Veldhuisen, D.J.; Sattar, N.; Krum, H.; Swedberg, K.; Shi, H.; Vincent, J.; Pocock, S.J.; Pitt, B.; Zannad, F.; et al. Eplerenone and new-onset diabetes in patients with mild heart failure: Results from the Eplerenone in Mild Patients Hospitalization and Survival Study in Heart Failure (EMPHASIS-HF). Eur. J. Heart Fail. 2012, 14, 909-915. [CrossRef] [PubMed]

97. Montalescot, G.; Pitt, B.; Lopez de Sa, E.; Hamm, C.W.; Flather, M.; Verheugt, F.; Shi, H.; Turgonyi, E.; Orri, M.; Vincent, J.; et al. Early eplerenone treatment in patients with acute ST-elevation myocardial infarction without heart failure: The Randomized Double-Blind Reminder Study. Eur. Heart J. 2014, 35, 2295-2302. [CrossRef] [PubMed] 
98. Guo, C.; Martinez-Vasquez, D.; Mendez, G.P.; Toniolo, M.F.; Yao, T.M.; Oestreicher, E.M.; Kikuchi, T.; Lapointe, N.; Pojoga, L.; Williams, G.H.; et al. Mineralocorticoid receptor antagonist reduces renal injury in rodent models of types 1 and 2 diabetes mellitus. Endocrinology 2006, 147, 5363-5373. [CrossRef]

99. Lian, M.; Hewitson, T.D.; Wigg, B.; Samuel, C.S.; Chow, F.; Becker, G.J. Long-term mineralocorticoid receptor blockade ameliorates progression of experimental diabetic renal disease. Nephrol. Dial. Transplant. 2012, 27, 906-912. [CrossRef]

100. Kang, Y.S.; Ko, G.J.; Lee, M.H.; Song, H.K.; Han, S.Y.; Han, K.H.; Kim, H.K.; Han, J.Y.; Cha, D.R. Effect of eplerenone, enalapril and their combination treatment on diabetic nephropathy in type II diabetic rats. Nephrol. Dial. Transplant. 2009, 24, 73-84. [CrossRef]

101. Zhou, G.; Johansson, U.; Peng, X.R.; Bamberg, K.; Huang, Y. An additive effect of eplerenone to ACE inhibitor on slowing the progression of diabetic nephropathy in the db/db mice. Am. J. Transl. Res. 2016, 8, 1339-1354.

102. Epstein, M.; Buckalew, V.; Martinez, F.; Altamirano, J.; Roniker, B.; Kleiman, J.; Krause, S.; Investigators, E. OR-54: Antiproteinuric efficacy of eplerenone, enalapril, and eplerenone/enalapril combination therapy in diabetic hypertensives with microalbuminuria. Am. J. Hypertens. 2002, 15, 24A. [CrossRef]

103. Epstein, M.; Williams, G.H.; Weinberger, M.; Lewin, A.; Krause, S.; Mukherjee, R.; Patni, R.; Beckerman, B. Selective aldosterone blockade with eplerenone reduces albuminuria in patients with type 2 diabetes. Clin. J. Am. Soc. Nephrol. 2006, 1, 940-951. [CrossRef] [PubMed]

104. Pérez-Gordillo, F.; Pérez de Vega, M.; Gerona-Navarro, G.; Rodríguez, Y.; de la Rosa, D.; González-Muñiz, R.; Martín-Martínez, M. Advances in the Development of Non-steroidal Mineralocorticoid-receptor Antagonists. In Aldosterone-Mineralocorticoid Receptor-Cell Biology to Translational Medicine; Harvey, B., Jaisser, F., Eds.; IntechOpen: London, UK, 2019.

105. Nakamura, T.; Kawaguchi, A. Phase 1 Studies to Define the Safety, Tolerability, and Pharmacokinetic and Pharmacodynamic Profiles of the Nonsteroidal Mineralocorticoid Receptor Antagonist Apararenone in Healthy Volunteers. Clin. Pharmacol. Drug Dev. 2021, 10, 353-365. [CrossRef] [PubMed]

106. Nakamura, T.; Shimizu, H.; Kawaguchi, A. Drug-Drug Interactions of the Nonsteroidal Mineralocorticoid Receptor Antagonist Apararenone With Midazolam, Warfarin, and Digoxin: A Phase 1 Studies in Healthy Volunteers. Clin. Ther. 2020, 42, 2171-2183.e2174. [CrossRef]

107. Wada, T.; Inagaki, M.; Yoshinari, T.; Terata, R.; Totsuka, N.; Gotou, M.; Hashimoto, G. Apararenone in patients with diabetic nephropathy: Results of a randomized, double-blind, placebo-controlled phase 2 dose-response study and open-label extension study. Clin. Exp. Nephrol. 2021, 25, 120-130. [CrossRef] [PubMed]

108. Kato, M.; Furuie, H.; Shimizu, T.; Miyazaki, A.; Kobayashi, F.; Ishizuka, H. Single- and multiple-dose escalation study to assess pharmacokinetics, pharmacodynamics and safety of oral esaxerenone in healthy Japanese subjects. Br. J. Clin. Pharmacol. 2018, 84, 1821-1829. [CrossRef] [PubMed]

109. Yamada, M.; Mendell, J.; Takakusa, H.; Shimizu, T.; Ando, O. Pharmacokinetics, Metabolism, and Excretion of [(14)C]Esaxerenone, a Novel Mineralocorticoid Receptor Blocker in Humans. Drug Metab. Dispos. 2019, 47, 340-349. [CrossRef] [PubMed]

110. Yamada, M.; Takei, M.; Suzuki, E.; Takakusa, H.; Kotsuma, M.; Washio, T.; Murayama, N.; Inoue, S.I.; Izumi, T. Pharmacokinetics, distribution, and disposition of esaxerenone, a novel, highly potent and selective non-steroidal mineralocorticoid receptor antagonist, in rats and monkeys. Xenobiotica 2017, 47, 1090-1103. [CrossRef] [PubMed]

111. Duggan, S. Esaxerenone: First Global Approval. Drugs 2019, 79, 477-481. [CrossRef] [PubMed]

112. Ito, S.; Itoh, H.; Rakugi, H.; Okuda, Y.; Yamakawa, S. Efficacy and safety of esaxerenone (CS-3150) for the treatment of essential hypertension: A phase 2 randomized, placebo-controlled, double-blind study. J. Hum. Hypertens. 2019, 33, 542-551. [CrossRef] [PubMed]

113. Ito, S.; Itoh, H.; Rakugi, H.; Okuda, Y.; Yoshimura, M.; Yamakawa, S. Double-Blind Randomized Phase 3 Study Comparing Esaxerenone (CS-3150) and Eplerenone in Patients With Essential Hypertension (ESAX-HTN Study). Hypertension 2020, 75, 51-58 [CrossRef]

114. Ito, S.; Itoh, H.; Rakugi, H.; Okuda, Y.; Iijima, S. Antihypertensive effects and safety of esaxerenone in patients with moderate kidney dysfunction. Hypertens. Res. 2021, 44, 489-497. [CrossRef]

115. Arai, K.; Tsuruoka, H.; Homma, T. CS-3150, a novel non-steroidal mineralocorticoid receptor antagonist, prevents hypertension and cardiorenal injury in Dahl salt-sensitive hypertensive rats. Eur. J. Pharmacol. 2015, 769, 266-273. [CrossRef] [PubMed]

116. Arai, K.; Morikawa, Y.; Ubukata, N.; Tsuruoka, H.; Homma, T. CS-3150, a Novel Nonsteroidal Mineralocorticoid Receptor Antagonist, Shows Preventive and Therapeutic Effects On Renal Injury in Deoxycorticosterone Acetate/Salt-Induced Hypertensive Rats. J. Pharmacol. Exp. Ther. 2016, 358, 548-557. [CrossRef]

117. Li, L.; Guan, Y.; Kobori, H.; Morishita, A.; Kobara, H.; Masaki, T.; Nakano, D.; Nishiyama, A. Effects of the novel nonsteroidal mineralocorticoid receptor blocker, esaxerenone (CS-3150), on blood pressure and urinary angiotensinogen in low-renin Dahl salt-sensitive hypertensive rats. Hypertens. Res. 2019, 42, 769-778. [CrossRef]

118. Bhuiyan, A.S.; Rafiq, K.; Kobara, H.; Masaki, T.; Nakano, D.; Nishiyama, A. Effect of a novel nonsteroidal selective mineralocorticoid receptor antagonist, esaxerenone (CS-3150), on blood pressure and renal injury in high salt-treated type 2 diabetic mice. Hypertens. Res. 2019, 42, 892-902. [CrossRef]

119. Arai, K.; Morikawa, Y.; Ubukata, N.; Sugimoto, K. Synergistic reduction in albuminuria in type 2 diabetic mice by esaxerenone (CS-3150), a novel nonsteroidal selective mineralocorticoid receptor blocker, combined with an angiotensin II receptor blocker. Hypertens. Res. 2020, 43, 1204-1213. [CrossRef] [PubMed] 
120. Itoh, H.; Ito, S.; Rakugi, H.; Okuda, Y.; Nishioka, S. Efficacy and safety of dosage-escalation of low-dosage esaxerenone added to a RAS inhibitor in hypertensive patients with type 2 diabetes and albuminuria: A single-arm, open-label study. Hypertens. Res. 2019, 42, 1572-1581. [CrossRef]

121. Ito, S.; Shikata, K.; Nangaku, M.; Okuda, Y.; Sawanobori, T. Efficacy and Safety of Esaxerenone (CS-3150) for the Treatment of Type 2 Diabetes with Microalbuminuria: A Randomized, Double-Blind, Placebo-Controlled, Phase II Trial. Clin. J. Am. Soc. Nephrol. 2019, 14, 1161-1172. [CrossRef] [PubMed]

122. Ito, S.; Kashihara, N.; Shikata, K.; Nangaku, M.; Wada, T.; Okuda, Y.; Sawanobori, T. Esaxerenone (CS-3150) in Patients with Type 2 Diabetes and Microalbuminuria (ESAX-DN): Phase 3 Randomized Controlled Clinical Trial. Clin. J. Am. Soc. Nephrol. 2020, 15, 1715-1727. [CrossRef]

123. Pei, H.; Wang, W.; Zhao, D.; Wang, L.; Su, G.H.; Zhao, Z. The use of a novel non-steroidal mineralocorticoid receptor antagonist finerenone for the treatment of chronic heart failure: A systematic review and meta-analysis. Medicine 2018, 97, e0254. [CrossRef]

124. Kolkhof, P.; Delbeck, M.; Kretschmer, A.; Steinke, W.; Hartmann, E.; Bärfacker, L.; Eitner, F.; Albrecht-Küpper, B.; Schäfer, S. Finerenone, a novel selective nonsteroidal mineralocorticoid receptor antagonist protects from rat cardiorenal injury. J. Cardiovasc. Pharmacol. 2014, 64, 69-78. [CrossRef]

125. Lattenist, L.; Lechner, S.M.; Messaoudi, S.; Le Mercier, A.; El Moghrabi, S.; Prince, S.; Bobadilla, N.A.; Kolkhof, P.; Jaisser, F.; Barrera-Chimal, J. Nonsteroidal Mineralocorticoid Receptor Antagonist Finerenone Protects Against Acute Kidney InjuryMediated Chronic Kidney Disease: Role of Oxidative Stress. Hypertension 2017, 69, 870-878. [CrossRef]

126. Barrera-Chimal, J.; Estrela, G.R.; Lechner, S.M.; Giraud, S.; El Moghrabi, S.; Kaaki, S.; Kolkhof, P.; Hauet, T.; Jaisser, F. The myeloid mineralocorticoid receptor controls inflammatory and fibrotic responses after renal injury via macrophage interleukin-4 receptor signaling. Kidney Int. 2018, 93, 1344-1355. [CrossRef]

127. Grune, J.; Beyhoff, N.; Smeir, E.; Chudek, R.; Blumrich, A.; Ban, Z.; Brix, S.; Betz, I.R.; Schupp, M.; Foryst-Ludwig, A.; et al. Selective Mineralocorticoid Receptor Cofactor Modulation as Molecular Basis for Finerenone's Antifibrotic Activity. Hypertension 2018, 71, 599-608. [CrossRef]

128. Pitt, B.; Kober, L.; Ponikowski, P.; Gheorghiade, M.; Filippatos, G.; Krum, H.; Nowack, C.; Kolkhof, P.; Kim, S.Y.; Zannad, F. Safety and tolerability of the novel non-steroidal mineralocorticoid receptor antagonist BAY 94-8862 in patients with chronic heart failure and mild or moderate chronic kidney disease: A randomized, double-blind trial. Eur. Heart J. 2013, 34, $2453-2463$. [CrossRef] [PubMed]

129. Filippatos, G.; Anker, S.D.; Böhm, M.; Gheorghiade, M.; Køber, L.; Krum, H.; Maggioni, A.P.; Ponikowski, P.; Voors, A.A.; Zannad, F.; et al. A randomized controlled study of finerenone vs. eplerenone in patients with worsening chronic heart failure and diabetes mellitus and/or chronic kidney disease. Eur. Heart J. 2016, 37, 2105-2114. [CrossRef] [PubMed]

130. Agarwal, R.; Anker, S.D.; Bakris, G.; Filippatos, G.; Pitt, B.; Rossing, P.; Ruilope, L.; Gebel, M.; Kolkhof, P.; Nowack, C.; et al. Investigating new treatment opportunities for patients with chronic kidney disease in type 2 diabetes: The role of finerenone. Nephrol. Dial. Transplant. 2020. [CrossRef]

131. Bakris, G.L.; Agarwal, R.; Chan, J.C.; Cooper, M.E.; Gansevoort, R.T.; Haller, H.; Remuzzi, G.; Rossing, P.; Schmieder, R.E.; Nowack, C.; et al. Effect of Finerenone on Albuminuria in Patients With Diabetic Nephropathy: A Randomized Clinical Trial. Jama 2015, 314, 884-894. [CrossRef] [PubMed]

132. Bakris, G.L.; Agarwal, R.; Anker, S.D.; Pitt, B.; Ruilope, L.M.; Rossing, P.; Kolkhof, P.; Nowack, C.; Schloemer, P.; Joseph, A.; et al. Effect of Finerenone on Chronic Kidney Disease Outcomes in Type 2 Diabetes. N. Engl. J. Med. 2020, 383, 2219-2229. [CrossRef] [PubMed]

133. Filippatos, G.; Anker, S.D.; Agarwal, R.; Pitt, B.; Ruilope, L.M.; Rossing, P.; Kolkhof, P.; Schloemer, P.; Tornus, I.; Joseph, A.; et al. Finerenone and Cardiovascular Outcomes in Patients With Chronic Kidney Disease and Type 2 Diabetes. Circulation 2021, 143, 540-552. [CrossRef]

134. Ruilope, L.M.; Agarwal, R.; Anker, S.D.; Bakris, G.L.; Filippatos, G.; Nowack, C.; Kolkhof, P.; Joseph, A.; Mentenich, N.; Pitt, B. Design and Baseline Characteristics of the Finerenone in Reducing Cardiovascular Mortality and Morbidity in Diabetic Kidney Disease Trial. Am. J. Nephrol. 2019, 50, 345-356. [CrossRef] [PubMed]

135. Bayer's Finerenone Meets Primary Endpoint in Phase III FIGARO-DKD Cardiovascular Outcomes Study in Patients with chronic Kidney Disease and Type 2 Diabetes. Available online: https://media.bayer.com/baynews/baynews.nsf/id/F6AC5A8D4B064 7AAC12586D100282B80?open\&ref=irrefndcd (accessed on 15 May 2021). 